\title{
Sampling procedures for inventory of commercial volume tree species in Amazon Forest
}

\author{
SYLVIO P. NETTO ${ }^{1}$, ALLAN L. PELISSARI ${ }^{1}$, VINICIUS C. CYSNEIROS ${ }^{1}$, \\ MARCELO BONAZZA ${ }^{2}$ and CARLOS R. SANQUETTA ${ }^{1}$ \\ ${ }^{1}$ Engenharia Florestal, Universidade Federal do Paraná/UFPR, Av. Prof. Lothário \\ Meissner, 632, Jardim Botânico, 80210-170 Curitiba, PR, Brazil \\ ${ }^{2}$ Engenharia Florestal, Universidade Federal de Santa Catarina/UFSC, Rod. Ulysses \\ Gaboardi, Km 3, Pessegueirinho, 89520-000 Curitibanos, SC, Brazil
}

Manuscript received on November 4, 2016; accepted for publication on April 3, 2017

\begin{abstract}
The spatial distribution of tropical tree species can affect the consistency of the estimators in commercial forest inventories, therefore, appropriate sampling procedures are required to survey species with different spatial patterns in the Amazon Forest. For this, the present study aims to evaluate the conventional sampling procedures and introduce the adaptive cluster sampling for volumetric inventories of Amazonian tree species, considering the hypotheses that the density, the spatial distribution and the zero-plots affect the consistency of the estimators, and that the adaptive cluster sampling allows to obtain more accurate volumetric estimation. We use data from a census carried out in Jamari National Forest, Brazil, where trees with diameters equal to or higher than $40 \mathrm{~cm}$ were measured in 1,355 plots. Species with different spatial patterns were selected and sampled with simple random sampling, systematic sampling, linear cluster sampling and adaptive cluster sampling, whereby the accuracy of the volumetric estimation and presence of zero-plots were evaluated. The sampling procedures applied to species were affected by the low density of trees and the large number of zero-plots, wherein the adaptive clusters allowed concentrating the sampling effort in plots with trees and, thus, agglutinating more representative samples to estimate the commercial volume.
\end{abstract}

Key words: Adaptive cluster sampling, spatial species distribution, volume estimation, zero-plots.

\section{INTRODUCTION}

The Amazon Forest composes the richest collection of plant species on the planet, having approximately 16 thousand tree species, where approximately $50 \%$ of the trees are concentrated in only $1.4 \%$ of species (Ter Steege et al. 2013) in a flora composed of many rare species of restricted distribution

Correspondence to: Allan Libanio Pelissari

E-mail: allanpelissari@gmail.com
(Hopkins 2007). For this, the spatial patterns are frequently the focus of ecological researches, due to the high diversity in tropical forests that is characterized by low density of tax (Condit et al. 2000). This knowledge is important to inventories, especially those intended for production and conservation forests.

The spatial distributions of species are fundamental for ecological modeling (Condit et al. 2000), where they reflect recruitment and mortality 
patterns, autoecological characteristics, syndrome of dispersion and reproductive biology (Crawley 1986, Pianka 1994, Dale 1999). However, the spatial patterns can affect the consistency of the sampling procedures. If the pattern is aggregate, a sample with low number of plots can result in high or low density when the results are extrapolated to the population and, thus, appropriated sampling techniques are required (Odum and Barret 2008).

In Brazilian Amazon, conventional sampling procedures are constantly applied to estimate volumetric stock of species groups (Higuchi et al. 1982, Cavalcanti et al. 2011, Oliveira et al. 2014), where there are many rare and aggregate species responsible for high diversity that affect effectiveness of forest inventories. Nevertheless, there are no studies reported in the specialized literature about appropriate sampling techniques by specifics species with different spatial patterns in the Amazon Forest.

In many studies, the adaptive cluster sampling has proved to be a versatile tool for evaluating rare and aggregate populations, because by conventional sampling you cannot estimate well their parameters (Thompson 1990, Brown and Manly 1998, Talvitie et al. 2006). Initially, the adaptive sampling was developed by Thompson (1990), which compared the results of this procedure with the conventional ones, evaluating different populations and finding satisfactory results, especially for aggregate and rare events.

In the adaptive cluster sampling, the first level is based on conventional methods as random or systematic. Through detection of a species or interesting phenomenon in the plots, the second level is started and new plots are allocated contiguously to the first ones. The second level continues until the target phenomenon is not detected and, then, the construction of the clusters is interrupted. Furthermore, its sampling structure and their estimators are presented in Thompson
(1990), Acharya et al. (2000), Talvitie et al. (2006) and Lei et al. (2012).

Considering the hypotheses that (1) the low density of trees, the spatial distribution of species and the high number of zero-plots affect the consistency of the samplings in tropical forests; and that (2) the adaptive cluster sampling allows to obtain more accurate volumetric stocks; the present study aims to evaluate the conventional sampling procedures and introduce the adaptive cluster sampling to inventory of tree species in Amazon Forest.

\section{MATERIALS AND METHODS}

\section{STUDY AREA}

A census dataset of a native forest with 1,596 ha and located in the Jamari National Forest, Rondônia State, Brazil, was used to developed this study. The Jamari National Forest occupies an area between the coordinates $09^{\circ} 00^{\prime} 00^{\prime \prime} \mathrm{S}$ at $09^{\circ} 30^{\prime} 00^{\prime \prime} \mathrm{S}$ and $62^{\circ} 44^{\prime} 05^{\prime \prime} \mathrm{W}$ at $63^{\circ} 16^{\prime} 64^{\prime \prime} \mathrm{W}$ in the Southwest Amazon Forest, where all trees with diameter at 1.3 $\mathrm{m}$ above the ground equal to or greater than $40 \mathrm{~cm}$ were measured, identified and georeferenced in an Annual Production Unit divided in 1,355 plots of $50 \mathrm{~m} \times 250 \mathrm{~m}$.

\section{PHYTOSOCIOLOGICAL CHARACTERIZATION}

The forest structure was characterized by means of phytosociological descriptors (Müeller-Dombois and Ellenberg 1974) and diversity indices (Shannon and Weaver 1949, Simpson 1949, Pielou 1969). Also, the spatial patterns of species were classified through standardized Morisita's index (Morisita 1962) as random, with values between -0.5 and +0.5 ; uniform, characterized by values below -0.5 ; and aggregate, with values higher than +0.5 (Morisita 1962, Amaral et al. 2015). In addition, the Kernel density estimator (Silverman 1986) was applied to investigate the species density and their 
distributions, through ArcGIS 10.3 software and Spatial Analyst package (ESRI 2016).

\section{SAMPLING PROCEDURES}

Amazon tree species were selected considering different spatial patterns and the criteria of rarity, economic and social importance. Thus, the simple random, systematic, linear cluster and adaptive cluster sampling procedures were applied with $10 \%$ of the potential sampling units of $50 \mathrm{~m} \times 250 \mathrm{~m}$. In simple random sampling (Figure 1a), the plots were randomly allocated to each one of the selected species populations, while the systematic sampling units in single stage were distributed with regular intervals of $250 \mathrm{~m}$ between them (Figure 1b).

Furthermore, linear clusters were allocated randomly in the study area, being formed by four units of $50 \mathrm{~m} \times 250 \mathrm{~m}$ separated by plots of equal size (Figure 1c). For adaptive clusters, the first stage consisted in a random allocation of sampling units, and those that corresponded to the inclusion criterion of at least one tree were selected for the second stage; subsequently, their neighbor plots with one or more trees were incorporated into each cluster, forming their respective networks in the final stage (Figure 1d).

The estimated volume per hectare (1 to 3 ) and variance of the mean (4 to 7) were calculated for simple random sampling, systematic sampling, and linear cluster sampling (Péllico Netto and Brena 1997, Husch et al. 2002). While the modified Horvitz-Thompson estimators (Thompson 1990) were used and implemented by R statistical program (R Core Team 2013) for the adaptive clusters sampling. Furthermore, the standard error (8), relative sampling error (9), and confidence interval (10) were calculated for all sampling procedures.
Simple random and Systematic

Linear cluster

Adaptive cluster

Simple random

Systematic

Variance of the mean $\left(s_{\bar{x}}^{2}\right)$

$$
\bar{x}=\frac{\sum_{i=1}^{n} X_{i}}{n}
$$

Linear cluster

$$
s_{\bar{x}}^{2} \cong \frac{\sum_{i=1}^{n-1}\left(X_{i}-X_{i+1}\right)^{2}}{2 n(n-1)}(1-f)
$$

Adaptive cluster

$$
\begin{aligned}
& s_{\bar{x}}^{2}=\frac{s_{x}^{2}}{n M}[1+r(M-1)] \\
& s_{\bar{x}}^{2}=\frac{1}{N^{2}}\left[\sum_{j=1}^{K} \sum_{k=1}^{K} \frac{y_{j}^{*} y_{k}^{*}}{\alpha_{j k}}\left(\frac{\alpha_{j k}}{\alpha_{j} \alpha_{k}}-1\right)\right]
\end{aligned}
$$


Standard error $\left(s_{\bar{x}}\right)$

Relative sampling error $(E \%)$
$S_{\bar{x}}=\sqrt{s_{\bar{x}}^{2}}$

$$
E \%= \pm \frac{t s_{\bar{x}}}{\bar{x}} 100
$$

$$
I C\left[\bar{x}-t s_{\bar{x}} \leq \mu \leq \bar{x}+t s_{\bar{x}}\right]=P
$$

Where: $n=$ number of units sampled, $X_{i}=$ volume of the sample unit $i, X_{i j}=$ volume of unit $i$ in linear clusters $j, M=$ number of subunits of linear clusters, $N=$ number of potential sample units, $k=$ number of networks of the adaptive clusters present in the sample on the first sampling level, $y_{k}^{*}=$ sum of observations of the net $k$ of the adaptive clusters $k, \alpha_{k}=$ probability of initial sample belong to network $k, \alpha_{j k}=$ probability of initial sample to include at least one sampling unit in each network $j$ and $k, s_{x}^{2}=$ sample variance of volume, $f=\frac{n}{N}, t=$ value of student's $t$ distribution, and $P=$ associated probability of $95 \%$.

\section{a. Simple random sampling}

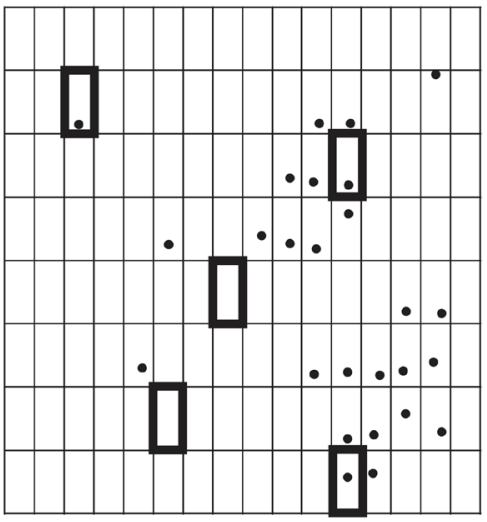

(First stage)

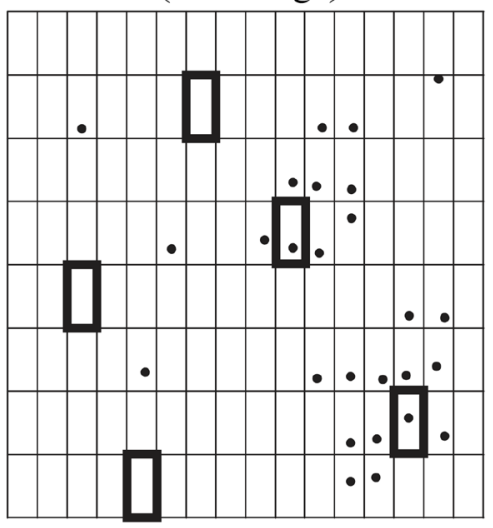

b. Systematic sampling

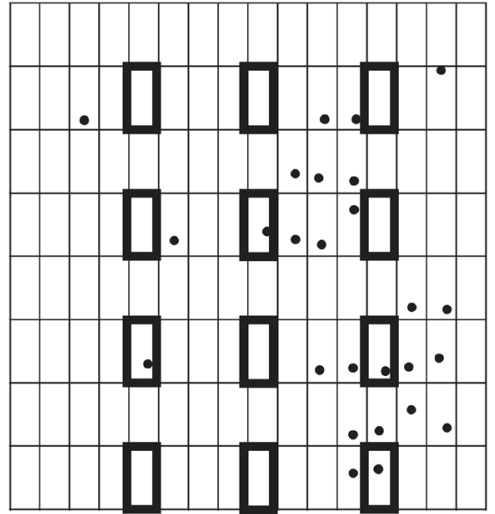

d. Adaptive cluster sampling

(Second stage)

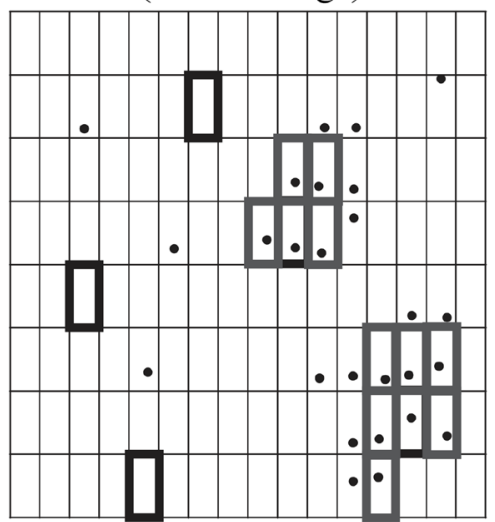

c. Linear clusters sampling

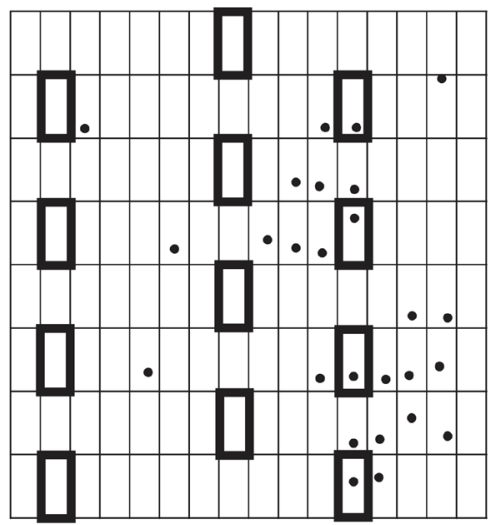

Figure 1 - Plots allocation structure in the sampling procedures.

(Final stage)

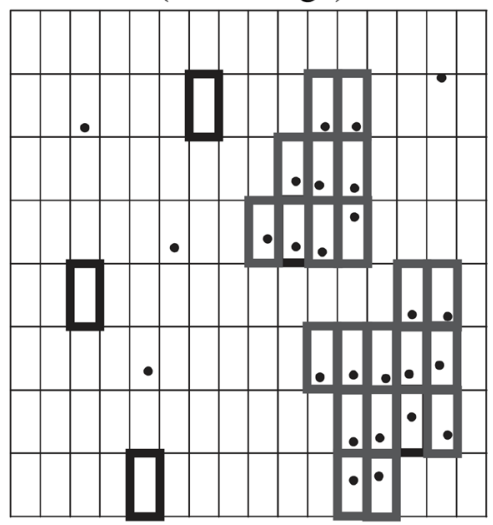


Thereby, for each sampling procedure and species, the statistical consistency was evaluated through $Z$ test at significance level of 0.05 , using the mean census volume $(\mu)$ as the reference value. The following hypotheses were tested: null $\left(H_{0}\right)$, when there is no rejection of equality between the mean volume of sample and census $\left(H_{0}: \bar{X}=\mu\right)$ ; and alternative $\left(H_{1}\right)$, when there is rejection of this equality $\left(H_{1}: \bar{X} \neq \mu\right)$. Also, the relative errors were evaluated, and the zero-plots, without trees (Heinsdijk 1965), were quantified in the sampling procedures.

\section{RESULTS}

In the census, 17,557 trees were sampled of 67 species (Table I), where Fabaceae was the family with highest floristic richness (24 species), followed by Vochysiaceae with five species, and

a.

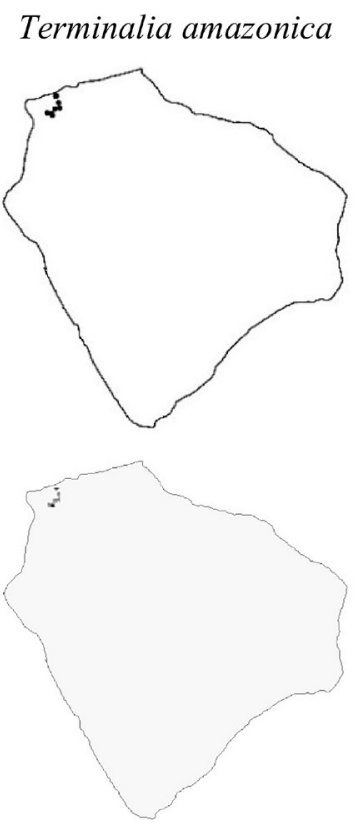

- Trees b. Apuleia leiocarpa
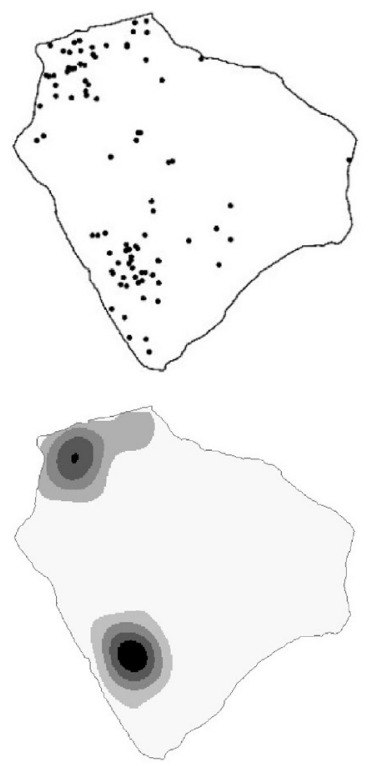

c.

Cedrela fissilis
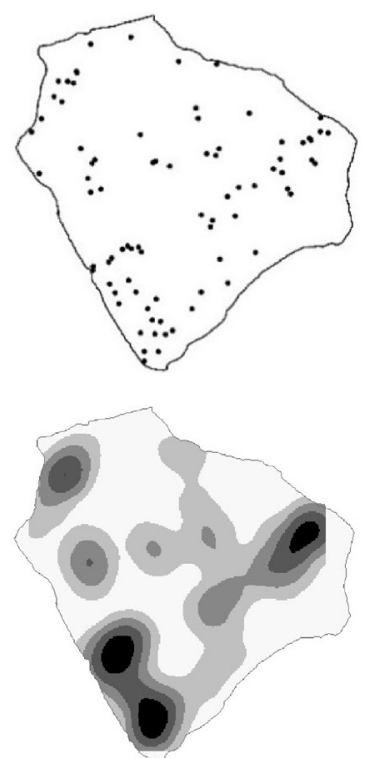

Species density

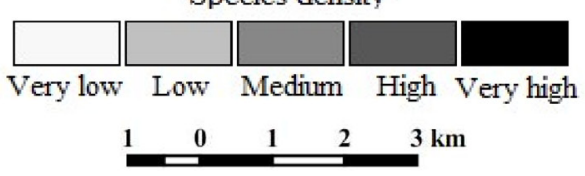

d.

Bertholletia excelsa
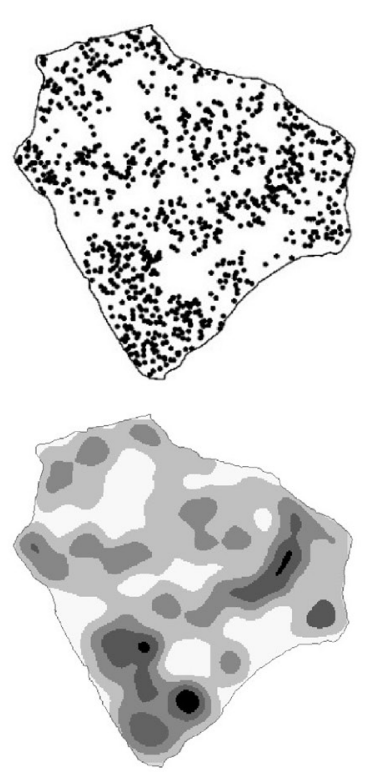

Figure 2 - Spatial distribution of the commercial tree species in Jamari National Forest, Brazilian Amazon. 
TABLE I

Phytosociological descriptors of the commercial tree species in Jamari National Forest, Brazilian Amazon.

\begin{tabular}{|c|c|c|c|c|c|c|c|c|}
\hline Species & Family & $N$ & $D \%$ & $F \%$ & Do\% & $V I \%$ & \multicolumn{2}{|c|}{ Morisita's index } \\
\hline Dinizia excelsa Ducke & Fabaceae & 986 & 5.62 & 4.67 & 13.11 & 7.80 & 0.50 & Aggregate \\
\hline Peltogyne paniculata Benth. & Fabaceae & 1,598 & 9.10 & 6.62 & 5.89 & 7.20 & 0.50 & Aggregate \\
\hline Astronium lecointei Ducke & Anacardiaceae & 1,296 & 7.38 & 5.84 & 6.35 & 6.53 & 0.50 & Aggregate \\
\hline Bertholletia excelsa Humb. \& Bonpl. & Lecythidaceae & 904 & 5.15 & 4.89 & 8.93 & 6.32 & 0.50 & Aggregate \\
\hline Cariniana micrantha Ducke & Lecythidaceae & 676 & 3.85 & 3.86 & 6.90 & 4.87 & 0.50 & Aggregate \\
\hline Huberodendron swietenioides (Gleason) Ducke & Malvaceae & 828 & 4.72 & 4.03 & 4.81 & 4.52 & 0.50 & Aggregate \\
\hline Tachigali sp. & Fabaceae & 807 & 4.60 & 3.94 & 3.28 & 3.94 & 0.50 & Aggregate \\
\hline Couratari stellata A. C. Sm. & Lecythidaceae & 581 & 3.31 & 3.51 & 3.91 & 3.58 & 0.50 & Aggregate \\
\hline Copaifera multijuga Hayne & Fabaceae & 690 & 3.93 & 3.83 & 2.38 & 3.38 & 0.50 & Aggregate \\
\hline Clarisia racemosa Ruíz \& Pav. & Moraceae & 636 & 3.62 & 3.42 & 2.40 & 3.15 & 0.50 & Aggregate \\
\hline Aspidosperma sp. & Apocynaceae & 514 & 2.93 & 3.07 & 3.10 & 3.03 & 0.50 & Aggregate \\
\hline Protium robustum (Swart) D.M. Porter & Burseraceae & 658 & 3.75 & 3.01 & 2.12 & 2.96 & 0.50 & Aggregate \\
\hline Hymenolobium heterocarpum Ducke & Fabaceae & 456 & 2.60 & 2.89 & 3.14 & 2.87 & 0.33 & Random \\
\hline Pouteria guianensis Aubl. & Sapotaceae & 565 & 3.22 & 3.17 & 2.04 & 2.81 & 0.50 & Aggregate \\
\hline Dipteryx odorata (Aubl.) Willd. & Fabaceae & 405 & 2.31 & 2.64 & 2.03 & 2.33 & 0.41 & Random \\
\hline Caryocar glabrum Pers. & Caryocaraceae & 359 & 2.04 & 2.44 & 1.96 & 2.15 & -0.17 & Random \\
\hline Goupia glabra Aubl. & Goupiaceae & 343 & 1.95 & 2.19 & 2.11 & 2.09 & 0.50 & Aggregate \\
\hline Erisma bicolor Ducke & Vochysiaceae & 336 & 1.91 & 2.20 & 1.74 & 1.95 & 0.50 & Aggregate \\
\hline Qualea paraensis Ducke & Vochysiaceae & 354 & 2.02 & 2.23 & 1.39 & 1.88 & 0.50 & Aggregate \\
\hline Allantoma decandra (Ducke) & Lecythidaceae & 292 & 1.66 & 1.96 & 1.78 & 1.80 & 0.39 & Random \\
\hline Vataireopsis speciosa Ducke & Fabaceae & 302 & 1.72 & 2.05 & 1.23 & 1.67 & 0.15 & Random \\
\hline Brosimum rubescens Taub. & Moraceae & 287 & 1.63 & 1.92 & 1.33 & 1.63 & 0.50 & Aggregate \\
\hline Hymenaea palustris Ducke & Fabaceae & 261 & 1.49 & 1.75 & 1.13 & 1.45 & 0.50 & Aggregate \\
\hline Brosimum sp. & Moraceae & 230 & 1.31 & 1.59 & 1.11 & 1.33 & 0.20 & Random \\
\hline Erisma fuscum Ducke & Vochysiaceae & 235 & 1.34 & 1.52 & 1.09 & 1.32 & 0.50 & Aggregate \\
\hline Vatairea guianensis Aubl. & Fabaceae & 235 & 1.34 & 1.56 & 1.00 & 1.30 & 0.50 & Aggregate \\
\hline Cedrelinga cateniformis (Ducke) Ducke & Fabaceae & 166 & 0.95 & 1.03 & 1.77 & 1.25 & 0.50 & Aggregate \\
\hline Iryanthera paradoxa (Schwacke) Warb. & Myristicaceae & 223 & 1.27 & 1.53 & 0.86 & 1.22 & 0.34 & Random \\
\hline $\begin{array}{c}\text { Handroanthus incanus (A.H. Gentry) S. O. } \\
\text { Grose }\end{array}$ & Bignoniaceae & 168 & 0.96 & 1.20 & 0.98 & 1.05 & 0.05 & Random \\
\hline Caryocar villosum (Aubl.) Pers. & Caryocaraceae & 148 & 0.84 & 1.05 & 1.04 & 0.98 & 0.26 & Random \\
\hline Minquartia guianensis Aubl. & Olacaceae & 183 & 1.04 & 1.27 & 0.58 & 0.96 & 0.48 & Random \\
\hline Parkia pendula (Willd.) Benth. ex Walp. & Fabaceae & 130 & 0.74 & 0.94 & 1.09 & 0.92 & 0.18 & Random \\
\hline Enterolobium schomburgkii (Benth.) Benth. & Fabaceae & 149 & 0.85 & 1.07 & 0.74 & 0.89 & 0.43 & Random \\
\hline Simarouba amara Aubl. & Simaroubaceae & 162 & 0.92 & 1.10 & 0.54 & 0.85 & 0.50 & Aggregate \\
\hline Mezilaurus synandra (Mez) Kosterm. & Lauraceae & 146 & 0.83 & 1.00 & 0.61 & 0.82 & 0.50 & Aggregate \\
\hline $\begin{array}{l}\text { Handroanthus impetiginosus (Mart. ex DC.) } \\
\text { Mattos }\end{array}$ & Bignoniaceae & 108 & 0.62 & 0.74 & 0.73 & 0.70 & 0.50 & Aggregate \\
\hline Bowdichia nitida Spruce ex Benth. & Fabaceae & 109 & 0.62 & 0.81 & 0.42 & 0.62 & -0.17 & Random \\
\hline
\end{tabular}


TABLE I (continuation)

\begin{tabular}{|c|c|c|c|c|c|c|c|c|}
\hline Species & Family & $N$ & $D \%$ & $F \%$ & Do\% & $V I \%$ & \multicolumn{2}{|c|}{ Morisita's index } \\
\hline Apuleia leiocarpa (Vogel) J.F.Macbr. & Fabaceae & 89 & 0.51 & 0.59 & 0.65 & 0.58 & 0.50 & Aggregate \\
\hline Martiodendron elatum (Ducke) Gleason & Fabaceae & 97 & 0.55 & 0.71 & 0.43 & 0.56 & 0.21 & Random \\
\hline Diplotropis rodriguesii H.C. Lima & Fabaceae & 100 & 0.57 & 0.74 & 0.33 & 0.54 & 0.05 & Random \\
\hline Manilkara elata (Allemão ex Miq.) Monach. & Sapotaceae & 91 & 0.52 & 0.70 & 0.35 & 0.52 & -0.45 & Random \\
\hline Cedrela fissilis Vell. & Meliaceae & 81 & 0.46 & 0.61 & 0.33 & 0.47 & -0.06 & Random \\
\hline Peltogyne venosa (Vahl) Benth. & Fabaceae & 77 & 0.44 & 0.54 & 0.35 & 0.44 & 0.50 & Aggregate \\
\hline Laetia procera (Poepp.) Eichler & Salicaceae & 76 & 0.43 & 0.57 & 0.27 & 0.42 & -0.02 & Random \\
\hline Virola sp. & Myristicaceae & 67 & 0.38 & 0.50 & 0.19 & 0.36 & 0.07 & Random \\
\hline Dipteryx alata Vogel & Fabaceae & 57 & 0.32 & 0.43 & 0.22 & 0.33 & -0.04 & Random \\
\hline Cordia goeldiana Huber & Boraginaceae & 50 & 0.28 & 0.36 & 0.20 & 0.28 & 0.50 & Aggregate \\
\hline Hevea guianensis Aubl. & Euphorbiaceae & 45 & 0.26 & 0.31 & 0.14 & 0.23 & 0.50 & Aggregate \\
\hline Jacaranda copaia (Aubl.) D.Don & Bignoniaceae & 39 & 0.22 & 0.30 & 0.14 & 0.22 & -0.19 & Random \\
\hline Qualea sp. & Vochysiaceae & 39 & 0.22 & 0.27 & 0.14 & 0.21 & 0.50 & Aggregate \\
\hline Parkia multijuga Benth. & Fabaceae & 25 & 0.14 & 0.18 & 0.13 & 0.15 & 0.50 & Aggregate \\
\hline Bagassa guianensis Aubl. & Moraceae & 24 & 0.14 & 0.17 & 0.10 & 0.14 & 0.50 & Aggregate \\
\hline $\begin{array}{l}\text { Osteophloeum platyspermum } \\
\text { (Spruce ex A. DC.) Warb. }\end{array}$ & Myristicaceae & 15 & 0.09 & 0.10 & 0.07 & 0.09 & 0.51 & Aggregate \\
\hline Zollernia paraensis Huber & Fabaceae & 15 & 0.09 & 0.11 & 0.05 & 0.08 & -0.07 & Random \\
\hline Pouteria eugeniifolia (Pierre) Baehni & Sapotaceae & 11 & 0.06 & 0.07 & 0.05 & 0.06 & 0.51 & Aggregate \\
\hline Terminalia amazonica (J.F.Gmel) Exell. & Combretaceae & 7 & 0.04 & 0.03 & 0.04 & 0.04 & 0.59 & Aggregate \\
\hline Hymenolobium modestum Ducke & Fabaceae & 5 & 0.03 & 0.04 & 0.04 & 0.03 & -0.02 & Random \\
\hline Aspidosperma sandwithianum Markgr. & Apocynaceae & 6 & 0.03 & 0.05 & 0.02 & 0.03 & -0.03 & Random \\
\hline Coccoloba latifolia Lam. & Polygonaceae & 3 & 0.02 & 0.02 & 0.03 & 0.02 & -0.01 & Random \\
\hline Anacardium parviflorum Ducke & Anacardiaceae & 3 & 0.02 & 0.02 & 0.02 & 0.02 & -0.01 & Random \\
\hline Vochysia sp. & Vochysiaceae & 3 & 0.02 & 0.02 & 0.02 & 0.02 & -0.01 & Random \\
\hline Trattinnickia rhoifolia Willd* & Burseraceae & 1 & 0.01 & 0.01 & 0.03 & 0.02 & - & - \\
\hline Lueheopsis rosea (Ducke) Burret* & Malvaceae & 1 & 0.01 & 0.01 & 0.01 & 0.01 & - & - \\
\hline Parkia sp.* & Fabaceae & 1 & 0.01 & 0.01 & 0.01 & 0.01 & - & - \\
\hline Hymenaea intermedia Ducke* & Fabaceae & 1 & 0.01 & 0.01 & 0.00 & 0.01 & - & - \\
\hline Aspidosperma sp.* & Apocynaceae & 1 & 0.01 & 0.01 & 0.00 & 0.01 & - & - \\
\hline Inga edulis Mart.* & Fabaceae & 1 & 0.01 & 0.01 & 0.00 & 0.01 & - & - \\
\hline Total & & 14,666 & 100 & 100 & 100 & 100 & & \\
\hline
\end{tabular}

Where: $N=$ number of trees, $D \%=$ density, $F \%=$ frequency, $D o \%=$ dominance, $V I \%=$ value of importance, $*=$ it was not possible to calculate the Morisita's Index for these species, because occurred only one tree in the population, and highlighted lines $=$ indicate de species selected in this study. 
were higher in locations with trees and decreased with increasing distance from these points.

When the Morisita's index was applied (Table I), the random spatial distribution was observed for Cedrela fissilis, while the aggregate pattern was identified for Apuleia leiocarpa and Bertholletia excelsa, as well as for Terminalia amazonica that showed the highest level of aggregation and one of the greatest levels of rarity with density $(D \%)$ equal to $0.04 \%$. Considering all species, $44.26 \%$ were classified as random, $55.73 \%$ as aggregate, and none with uniform distribution.

By means of the $Z$ test at significance level of 0.05 (Table II), the null hypothesis was rejected only for mean volume $(\bar{x})$ in systematic sampling applied for Apuleia leiocarpa. However, statistical differences in association to the census $(\mu)$ were not found between the estimates by others sampling procedures, resulting in consistent confidence intervals $(C I)$ for the means of studied species.

High relative errors $(E \%)$ were observed for the selected species (Table II), especially for Terminalia amazonica, for which the application of adaptive cluster sampling increases the accuracy, as well as for Bertholletia excelsa and Cedrella fissilis. However, linear clusters were not effective for Terminalia amazonica, but they were superior than other procedures applied to Apuleia leiocarpa.

Regarding the percentage of zero-plots observed in each sampling procedure (Figure 3), lower values were observed when using adaptive cluster sampling, mainly to Bertholletia excelsa (Figure 3d). Moreover, the absence of trees per sampling unit resulted in zero-plots frequencies near to $100 \%$ for Terminalia amazonica (Figure 3a), Apuleia leiocarpa (Figure 3b) and Cedrela fissilis (Figure 3c).

\section{DISCUSSION}

According to the selected species with distinct spatial distribution patterns (Figure 2), Apuleia leiocarpa and Cedrela fissilis have wood with high commercial value (Carvalho 2003) and wide geographical distribution in the Amazon territory (Pennington 1981, Oliveira Filho and Fontes 2000). Terminalia amazonica is commonly cultivated in Central America due to its fast growth (Piotto et al. 2003, Moya et al. 2009), while Bertholletia excelsa is the most relevant Amazonian species for nontimber purposes (Thomas et al. 2014), whose nuts are important for sustaining the Amazonian rural communities (Salomão 2009).

The Morisita's index equal to 0.59 for Terminalia amazonica was the largest among the species (Table I), while the aggregate distribution (0.50) found for Apuleia leiocarpa and Bertholletia excelsa is common among tropical species due to soil conditions and syndrome of species dispersion (Condit et al. 2000, Plotkin et al. 2000, Seidler and Plotkin 2006). The random distribution (-0.06) for Cedrela fissilis is less frequent, because it implies in more homogeneity of environment or in less specificity of the habitat (Matteucci and Colma 1982).

In this context, to compare the influence of environmental factors in the distribution of Amazonian tree species, Barroso et al. (2011) concluded that the soil attributes affect the abundance of species, although present a weak correlation with species occurrence. However, Apuleia leiocarpa (Figure 2b) and Cedrela fissilis (Figure 2c) holds high commercial value and, thus, the historical factors of the exploitation can reveal a strong influence on their current spatial distributions (Tassin and Riviere 2003), since the study area is inserted into a region of intense timber exploitation.

Bertholletia excelsa was observed in groups that ranged in size and number of trees (Figure $2 \mathrm{~d}$ ), and associated to other large trees on not flooded lands, where the natural clearings and the dispersion of its fruits by animals expand the population (Salomão 2009, Thomas et al. 2014). 
TABLE II

Commercial volume estimation and percentage of zero-plots by sampling procedures in Jamari National Forest, Brazilian Amazon.

\begin{tabular}{|c|c|c|c|c|c|}
\hline \multirow{2}{*}{ Sampling procedure } & $\mu$ & $\bar{x}$ & \multirow{2}{*}{$E \%$} & CI & \multirow{2}{*}{$z-p \%$} \\
\hline & \multicolumn{2}{|c|}{$\left(\mathrm{m}^{3} \mathrm{ha}^{-1}\right)$} & & $\left(\mathrm{m}^{3} \mathrm{ha}^{-1}\right)$ & \\
\hline \multicolumn{6}{|c|}{ Terminalia amazonica } \\
\hline Simple random & \multirow{4}{*}{0.017} & $0.051^{\mathrm{ns}}$ & $187.6 \%$ & $0.000 \leq \mu \leq 0.148$ & $99.3 \%$ \\
\hline Systematic & & $0.035^{\mathrm{ns}}$ & $189.1 \%$ & $0.000 \leq \mu \leq 0.101$ & $99.2 \%$ \\
\hline Linear cluster & & - & - & - & $100 \%$ \\
\hline Adaptive cluster & & $0.083^{\mathrm{ns}}$ & $116.0 \%$ & $0.000 \leq \mu \leq 0.178$ & $97.8 \%$ \\
\hline \multicolumn{6}{|c|}{ Apuleia leiocarpa } \\
\hline Simple random & \multirow{4}{*}{0.439} & $0.255^{\text {ns }}$ & $82.8 \%$ & $0.044 \leq \mu \leq 0.467$ & $95.6 \%$ \\
\hline Systematic & & $0.095^{*}$ & $146.9 \%$ & $0.000 \leq \mu \leq 0.234$ & $98.4 \%$ \\
\hline Linear cluster & & $0.463^{\mathrm{ns}}$ & $69.1 \%$ & $0.143 \leq \mu \leq 0.783$ & $93.4 \%$ \\
\hline Adaptive cluster & & $0.278^{\mathrm{ns}}$ & $74.8 \%$ & $0.070 \leq \mu \leq 0.486$ & $83.6 \%$ \\
\hline \multicolumn{6}{|c|}{ Cedrela fissilis } \\
\hline Simple random & \multirow{4}{*}{0.265} & $0.267^{\mathrm{ns}}$ & $66.1 \%$ & $0.091 \leq \mu \leq 0.443$ & $94.1 \%$ \\
\hline Systematic & & $0.213^{\mathrm{ns}}$ & $68.7 \%$ & $0.067 \leq \mu \leq 0.360$ & $94.5 \%$ \\
\hline Linear cluster & & $0.277^{\mathrm{ns}}$ & $73.6 \%$ & $0.073 \leq \mu \leq 0.480$ & $94.1 \%$ \\
\hline Adaptive cluster & & $0.288^{\mathrm{ns}}$ & $64.9 \%$ & $0.101 \leq \mu \leq 0.475$ & $92.1 \%$ \\
\hline \multicolumn{6}{|c|}{ Bertholletia excelsa } \\
\hline Simple random & \multirow{4}{*}{3.704} & $3.821^{\mathrm{ns}}$ & $20.3 \%$ & $3.043 \leq \mu \leq 4.598$ & $51.5 \%$ \\
\hline Systematic & & $3.980^{\mathrm{ns}}$ & $22.2 \%$ & $3.097 \leq \mu \leq 4.863$ & $50.4 \%$ \\
\hline Linear cluster & & $3.216^{\mathrm{ns}}$ & $25.3 \%$ & $2.404 \leq \mu \leq 4.028$ & $59.6 \%$ \\
\hline Adaptive cluster & & $3.746^{\mathrm{ns}}$ & $20.2 \%$ & $2.990 \leq \mu \leq 4.502$ & $14.2 \%$ \\
\hline
\end{tabular}

Where: $\mu=$ mean volume (census), $\bar{x}=$ mean sample volume, $E \%=$ relative sampling error, $C I=$ confidence interval, $z-p \%=$ percentage of zero-plots, $\mathrm{ns}=$ no rejection of equality between the mean volume of sample and census, and $*=$ rejection of the equality by $Z$ test at significance level of 0.05 .

In addition to these factors, archaeological and historical evidences suggest the influence of the man, through collecting and cultivation, on the spatial distribution of the species (Peres et al. 2003, Thomas et al. 2014).

In inventories carried out in the Amazon Forest, the random, systematic and cluster sampling procedures are the most commonly applied (Higuchi 1987, Ubialli et al. 2009, Cavalcanti et al. 2011, Queiroz et al. 2011, Andrade et al. 2015). However, in approaches by species, these procedures have not shown satisfactory performance in the estimates of the present study (Table II), possibly due to low density of trees that affect the composition of representative samples, especially for Terminalia amazonica and, thus, confirming the first hypothesis of this study.

The spatial patterns (Figure 2) affected in the effectiveness of the sampling procedures (Table II), endorsing the first hypothesis, whose spatial behaviors are concomitant effects of several mechanisms, as dispersion, predation, pathogenic disease, tolerance, germination and competition (Myster and Malahay 2012). On the other hand, the abiotic factors, such as topography and lighting, also influencing on the dispersal of species (Svenning 1999), turn the comprehension of aspects that determine the distribution pattern of tropical species more complex (Table II). 
a. Terminalia amazonica

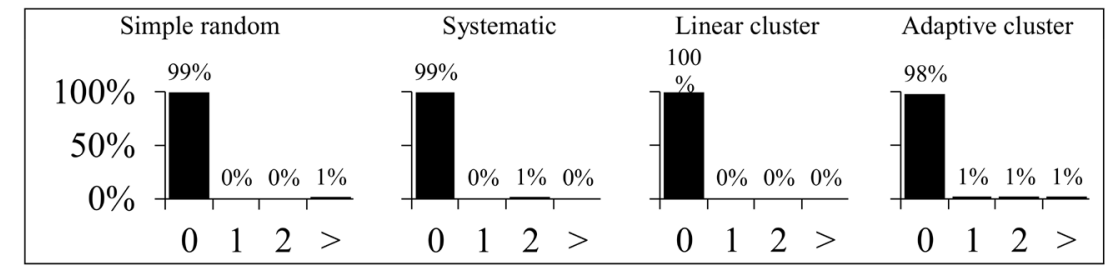

b. Apuleia leiocarpa

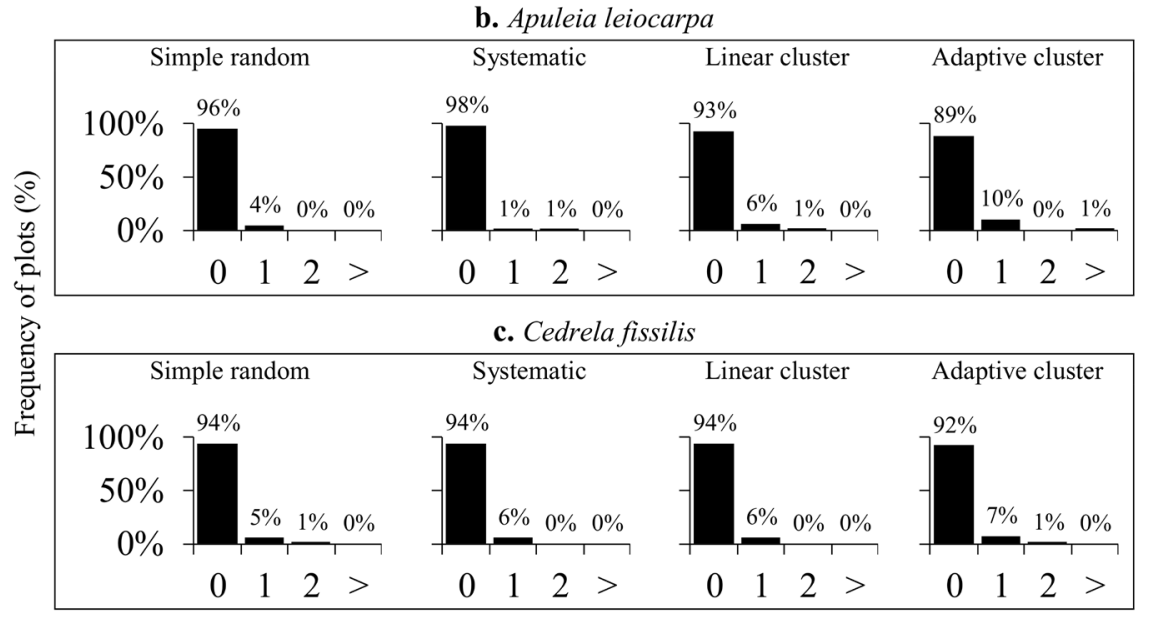

d. Bertholletia excelsa

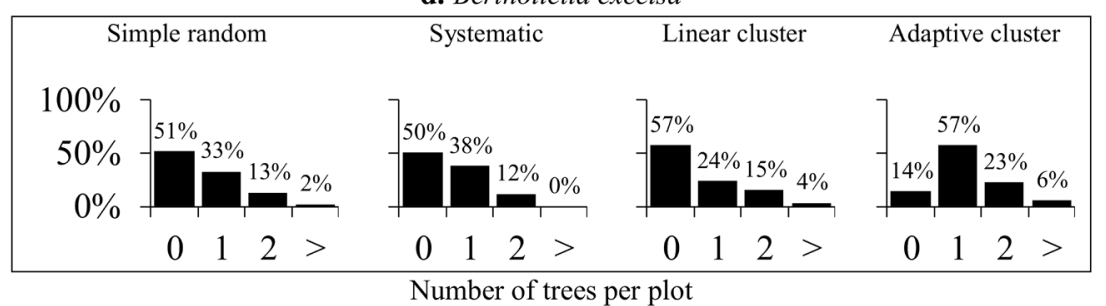

Figure 3 - Frequency of plots with zero, one, two or more than two trees for each species and sampling procedure in Jamari National Forest, Brazilian Amazon.

In addition, the high presence of zero-plots (Figure 3) interferes on the volumetric estimates, resulting in increase of the sampling error, which proves the first hypothesis (Table II). Therefore, the adaptive cluster sampling allowed to concentrate the sampling effort on non-zero-plots of the selected species. This enables us to maximize the efficiency of forest inventories and compose more representative samples for estimating commercial volume.

When applying adaptive cluster sampling, Talvitie et al. (2006) and Lei et al. (2012) observed that this procedure results in higher efficiency, when compared to conventional sampling procedures, highlighting its importance for surveying rare and aggregate populations. However, few studies have considered the problems of forest sampling with adaptive clusters (Roesch Jr 1993, Acharya et al. 2000), since the sub-sampling of rare species results in a considerable underestimation of the biodiversity (Hopkins 2007).

As an alternative to fixed area plots, sampling methods with probability proportional to size could reduce or eliminate the presence of zero-plots in the composition of samples. However, Prodan's points and Strand's lines have showed operationally impracticable, due to the area size and the difficulty to include trees of rare species in the sampling units. 
Thus, the results confirm the second hypothesis, that the adaptive cluster sampling reduces the zeroplots to estimate the commercial volume (Table II), and is a quite appropriated procedure for sampling rare populations of many kinds (Thompson 1990, Roesch Jr 1993, Brown 2003, Talvitie et al. 2006, Soares et al. 2009, Lei et al. 2012).

The estimator's effectiveness of the sampling procedures is directly related to spatial patterns, levels of aggregation and species density, where the adaptive clusters enable to concentrate the sampling effort to plots with occurrence of trees, reducing the percentage of zero-plots and maximizing the accuracy of commercial volume estimates in Amazon Forest inventories. However, the sampling procedures applied independently to species could result in unsatisfactory statistical performance in the volumetric estimations, due to the low density of individuals and to the high number of zero-plots.

\section{ACKNOWLEDGMENTS}

We thank to Conselho Nacional de Desenvolvimento Científico e Tecnológico - Brazil (CNPq) for a research scholarship and to Amata Company for providing the database.

\section{REFERENCES}

ACHARYA B, BHATTARAI G, GIER AAND STEIN A. 2000. Systematic adaptive cluster sampling for the assessment of rare tree species in Nepal. For Ecol Manage 137(1-3): 6573.

AMARAL MK, PÉLLICO NETTO S, LINGNAU C AND FIGUEIREDO FILHO A. 2015. Evaluation of the Morisita index for determination of the spatial distribution of species in a fragment of Araucaria Forest. Appl Ecol Env Res 13(2): 361-372.

ANDRADE DF, GAMA JRV, MELO LO AND RUSCHEL AR. 2015. Inventário florestal de grandes áreas na Floresta Nacional do Tapajós, Pará, Amazônia, Brasil. Biota Amaz 5(1): 109-115.

BARROSO JG, SALIMON CI, SILVEIRA M AND MORATO EF. 2011. Influência de fatores ambientais sobre a ocorrência e distribuição espacial de cinco espécies madeireiras exploradas no Estado do Acre, Brasil. Sci For 39(92): 489-499.
BROWN JA. 2003. Designing an efficient adaptive cluster sample. Environ Ecol Stat 10(1): 95-105.

BROWN JA AND MANLY BJF. 1998. Restricted adaptive cluster sampling. Environ Ecol Stat 5(1): 49-63.

CARVALHO PER. 2003. Espécies Arbóreas Brasileiras. Embrapa Florestas, Colombo, 1039 p.

CAVALCANTI FJB, MACHADO SAM, HOSOKAWA RT AND CUNHA US. 2011. Comparação dos valores estimados por amostragem na caracterização da estrutura de uma área de floresta na Amazônia com as informações registradas no censo florestal. Arvore 35(5): 1061-1068.

CONDIT R ET AL. 2000. Spatial patterns in the distribution of tropical tree species. Science 288(5470): 1414-1418.

CRAWLEY MJ. 1986. Plant Ecology. Blackwell Scientific Publications, Oxford, 496 p.

DALE MRT. 1999. Spatial Pattern Analysis in Plant Ecology. Cambridge University Press, Cambridge, $340 \mathrm{p}$.

ESRI - ENVIRONMENTAL SYSTEMS RESEARCH INSTITUTE. 2016. Software ArcGIS desktop: version 10.3. Redlands: Environmental Systems Research Institute.

HEINSDIJK D. 1965. Zero sampling units in forest inventories. Rio de Janeiro, 54 p.

HIGUCHI N. 1987. Amostragem Sistemática Versus Amostragem Aleatória em Floresta Tropical Úmida. Acta Amaz 16/17: 393-400.

HIGUCHI N, SANTOS J AND JARDIM FCS. 1982. Tamanho de parcela amostral para inventários florestais. Acta Amaz 12(1): 91-103.

HOPKINS MJG. 2007. Modelling the known and unknown plant biodiversity of the Amazon Basin. J Biogeogr 34(8): 1400-1411.

HUSCH B, MILLER CI AND BEERS TW. 2002. Forest mensuration. $4^{\text {th }}$. New York: J Wiley \& Sons, $456 \mathrm{p}$.

LEI Y, SHI J AND ZHAO T. 2012. Efficiency of adaptive cluster sampling and traditional sampling for coastal mangrove in Hainan of China. J For Scienc 58(9): 381390.

MATTEUCCI SD AND COLMA A. 1982. Metodologia para el estúdio de la vegetación. The General Secretarial of The Organization of American States, Washington, 168 p.

MORISITA M. 1962. Id-index, a Measure of Dispersion of Individuals. Res Popul Ecol 4: 1-7.

MOYA R, LEANDRO L AND MURILLO O. 2009. Wood characteristics of Terminalia amazonia, Vochysia guatemalensis and Hyeronima alchorneoides planted in Costa Rica. Bosques 30(2): 78-87.

MÜELLER-DOMBOIS D AND ELLENBERG H. 1974. Aims and methods of vegetation ecology. J Wiley \& Sons, New York, 547 p.

MYSTER RW AND MALAHY MP. 2012. Testing aggregation hypotheses among neotropical trees and shrubs: results from a 50-ha plot over 20 years of sampling. Rev Biol Trop 60(3): 1015-1023. 
ODUM EP AND BARRET GW. 2008. Fundamentos de Ecologia. CENGAGE Learning. São Paulo, 612 p.

OLIVEIRA MM, HIGUCHI N, CELES CH AND HIGUCHI FG. 2014. Tamanho e formas de parcelas para inventários florestais de espécies arbóreas na Amazônia Central. Cienc Florest 24(3): 645-653.

OLIVEIRA FILHO AT AND FONTES MAL. 2000. Patterns of floristic differentiation among Atlantic Forests in Southeastern Brazil and the influence of climate. Biotropica 32(4b): 793-810.

PÉLLICO NETTO S AND BRENA DA. 1997. Inventário florestal. Universidade Federal do Paraná, Curitiba, 316 p.

PENNINGTON TD. 1981. Meliaceae. Flora Neotropica 28: $1-470$.

PERES CA ET AL. 2003. Demographic threats to the sustainability of Brazil nut exploitation. Science 302(5653): 2112-2114.

PIANKA ER. 1994. Evolutionary Ecology. Harper Collins College Publishers, New York, 486 p.

PIELOU EC. 1969. An introduction to mathematical ecology. J Willy \& Sons. Inc., New York, 286 p.

PIOTTO DF, MONTAGNINI L, UGALDE M AND KANNINEN M. 2003. Performance of forest plantations in small and medium sized farms in the Atlantic lowlands of Costa Rica. For Ecol Manage 175(1-3): 195-204.

PLOTKIN JB, POTTS MD, LESLIE N, MANOKARAN N, LAFRANKIE J AND ASHTON PS. 2000. Species-area curves, spatial aggregation, and habitat specialization in tropical forests. J Theor Biol 207(1): 81-99.

QUEIROZ WT, PÉLLICO NETTO S, VALENTE MDR AND PINHEIRO JG. 2011. Análise estrutural da unidade conglomerada cruz de malta na Floresta Nacional do Tapajós, estado do Pará, Brasil. Floresta 41(1): 9-18.

R CORE TEAM. 2013. R: A language and environment for statistical computing. Vienna: R Foundation for Statistical Computing.

ROESCH JR FA. 1993. Adaptive cluster sampling for forest inventories. Forest Sci 39(4): 655-669.

SALOMÃO RP. 2009. Densidade, estrutura e distribuição espacial de castanheira-do-brasil (Bertholletia excelsa H. \& B.) em dois platôs de floresta ombrófila densa na
Amazônia setentrional brasileira. Bol Mus Para Emilio Goeldi Cienc Nat 4(1): 11-25.

SEIDLER TG AND PLOTKIN JB. 2006. Seed dispersal and spatial pattern in tropical tree. PLoS Biol 4(11): 21322137.

SHANNON CE AND WEAVER W. 1949. The mathematical theory of communication. University of Illinois Press, Urbana, $117 \mathrm{p}$.

SILVERMAN B. 1986. Density Estimation for Statistics and Data Analysis. London: Chapman and Hall.

SIMPSON EH. 1949. Measurement of diversity. Nature 163: 688-688.

SOARES CPB, RODELLO CM, SOUZA AL, LEITE HG, SOARES OS AND SILVA GF. 2009. Comparação entre procedimentos de amostragem para espécies florestais raras e padrão de distribuição espacial agregado. Arvore 33(3): 545-553.

SVENNING JC. 1999. Microhabitat specialization in a species-rich palm community in Amazonian Ecuador. J Ecol 87(1): 55-65.

TALVITIE M, LEINO O AND HOLOPAINEN M. 2006. Inventory of sparse forest populations using adaptive cluster sampling. Silva Fenn 40(1): 101-108.

TASSIN J AND RIVIERE JN. 2003. Species richness altitudinal gradient of invasive plants on Reunion Island (Mascareigne archipelago, Indian Ocean). Rev Ecol Terre Vie 58: 257-270.

TER STEEGE H ET AL. 2013. Hyperdominance in the Amazonian Tree Flora. Science 342(6156): 324-334.

THOMAS E, CAICEDO CA, LOO J AND KINDT R. 2014. The distribution of the Brazil nut (Bertholletia excelsa) through time: from range contraction in glacial refugia, over human-mediated expansion, to anthropogenic climate change. Bol Mus Goeldi 9(2): 267-291.

THOMPSON SK. 1990. Adaptive Cluster Sampling. J Am Stat Assoc 85(412): 1050-1059.

UBIALLI JA, FIGUEIREDO FILHO A, MACHADO AS AND ARCE JE. 2009. Comparação de métodos e processos de amostragem para estimar a área basal para grupos de espécies em uma floresta ecotonal da região norte mato-grossense. Acta Amaz 39(2): 305-314. 